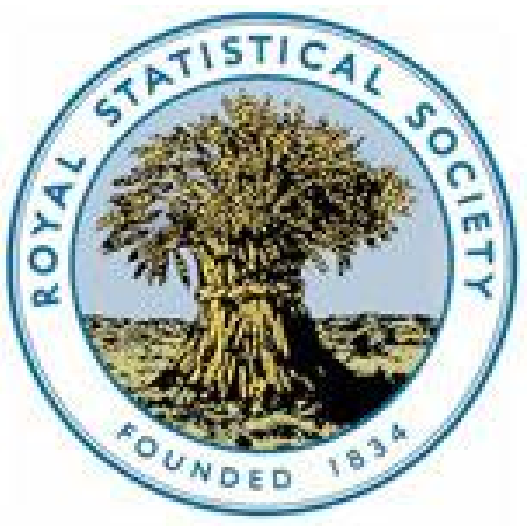

\title{
WILEY
}

\section{Crop Production and Price: A Note on Gregory King's Law} Author(s): G. Udny Yule

Source: Journal of the Royal Statistical Society, Vol. 78, No. 2 (Mar., 1915), pp. 296-298 Published by: Wiley for the Royal Statistical Society

Stable URL: http://www.jstor.org/stable/2340610

Accessed: 27-06-2016 04:10 UTC

Your use of the JSTOR archive indicates your acceptance of the Terms \& Conditions of Use, available at

http://about.jstor.org/terms

JSTOR is a not-for-profit service that helps scholars, researchers, and students discover, use, and build upon a wide range of content in a trusted digital archive. We use information technology and tools to increase productivity and facilitate new forms of scholarship. For more information about JSTOR, please contact support@jstor.org.

Royal Statistical Society, Wiley are collaborating with JSTOR to digitize, preserve and extend access to Journal of the Royal Statistical Society 
Crop Production and Price : A Note on Gregory King's Law.

$$
\text { By G. Udny Yule. }
$$

WhILE reading Professor Moore's volume on Economic Cycles reviewed elsewhere in this issue of the Journal, I was reminded, by his work on the relation between changes in the produce of the crops in the United States and changes in the price of the crop, of an old note of my own on the form of Gregory King's law. This law, as printed by Davenant,* is stated as follows: "We take it, "That a Defect in the Harvest may raise the Price of Corn in the "following Proportions.

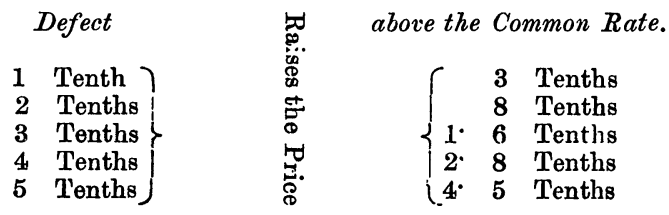

"So that when Corn rises to treble the Common Rate, it may be "presum'd, that we want above a third of the Common Produce; " and if we should want 5 Tenths, or half the Common Produce, "the Price would rise to near five times the Common Rate." The last figures are evidently to be read as "one and six tenths," i.e. sixteen tenths, and so on.

I do not know whether anyone has noticed the form of this law. The figures given form a three-difference series with the third difference unity: thus, inserting the zero with which the series should commence :-

$\begin{array}{rrrr} & \Delta^{1} & \Delta^{2} & \Delta^{3} \\ 0 & 3 & 2 & 1 \\ 3 & 5 & 3 & 1 \\ 8 & 8 & 4 & 1 \\ 16 & 12 & 5 & \\ 28 & 17 & & \\ 45 & & & \end{array}$

* Essay upon the probable methods of malcing a people gainers in the Ballance of Trade, 1699, p. 83. Whitworth's edition. Vol ii, p. 224. 
If we express the defect in production in its more usual modern form of a percentage $x$, and the rise in price similarly as a percentage $y$, the relation is

$$
\begin{aligned}
y & =-\frac{7}{3} x+\frac{1}{20} x^{2}-\frac{1}{6} \overline{0} x^{3} \\
& =-2 \cdot 33 x+0.05 x^{2}-0.00167 x^{3}
\end{aligned}
$$

Professor Moore takes as his variables the percentage change in production from one year to the next, and the corresponding percentage change in price. This may not come to quite the same thing as comparing deviations from the "Common' Produce" and the "Common Rate," for a fall of ro per cent., say, is treated by Professor Moore's method as of the same value whether it occurs from a normal level or from a level already low. Such as they are, however, let us put here his equations for crops in the United States of America, for comparison with Gregory King's equation of the same form for wheat in England, given more than a couple of centuries earlier :-

$$
\begin{array}{llll}
\text { Maize } & \ldots . & y=0.94-1.0399 x+0.02391 x^{2}-0.000234 x^{3} \\
\text { Hay.... } & \ldots . & y=4.17-0.9460 x-0.00770 x^{2}+0.000385 x^{3} \\
\text { Oats } & \ldots . & y=8.22-1.1904 x-0.006033 x^{2}+0.000273 x^{3} \\
\text { Potatoes } & \ldots . & y=1.77-1.5062 x+0.02489 x^{2}-0.000197 x^{3}
\end{array}
$$

The constant term only occurs in these equations because Professor Moore was dealing with a period in which the average change was a slight rise in price. The equations for maize and for potatoes are the only two of the four that agree in the sign of the terms with Gregory King's for wheat, and I think we may say they are the more rational of the four, since the equations for oats and hay would, for falls in production lying slightly outside the range of observation, give a decreasing rise, and ultimately a fall, in price. Omitting the constant term, Moore's equations for maize and potatoes would give figures comparing as follows with King's :-

\begin{tabular}{c|c|c|c}
\hline \multirow{2}{*}{$\begin{array}{c}\text { Percentage } \\
\text { defect in crop. }\end{array}$} & \multicolumn{3}{|c}{ Percentage rise in price according to } \\
\cline { 2 - 4 } & $\begin{array}{c}\text { Gregory King's } \\
\text { law for wheat. }\end{array}$ & \multicolumn{2}{|c}{ Moore's regression equations for } \\
\cline { 3 - 4 } & & Maize. & Potatoes. \\
\hline & 30 & 14 & 18 \\
10 & 80 & 33 & 42 \\
20 & 160 & 61 & 73 \\
30 & 280 & 97 & 113 \\
40 & 450 & 144 & 162 \\
50 & & & \\
\hline
\end{tabular}


Gregory King's law gives a much higher rise in price for a given deficiency in the harvest, but in the circumstances of the sixteenth and seventeenth centuries this seems probable enough.

The comparison makes one more curious than ever to know what estimates of production King used as a basis for his "law," and what suggested the particular form he gave it. From the form of the first-difference series one might conjecture an argument as follows, starting from a rough estimate that a fall of 1 tenth in the yield means a rise of 3 tenths in the price. A fall of a second tenth in the yield must mean a rise in the price very considerably greater than a further 3 tenths: perhaps as much as 5 tenths. That is, the first two tenths would together give a rise of 8 tenths in the price. A fall in yield of a third tenth must cause a greater rise again, and its increase in efficiency over the second tenth, in raising price, is probably greater than that of the second tenth over the first. Let us suppose then that instead of raising the price by a further 7 tenths it raises it by 8 tenths. That will make the combined effect of the first three tenths together a rise of 16 tenths in the price. And so on. But this is pure speculation. 